\title{
Zakat Analysis of Freelancer Profession
}

\author{
Mohammad Ghozali ${ }^{1 *}$, Abdul Hafidz Zaid ${ }^{1}$, A’yun Nadhira $^{1}$, Rahmah Fauziah ${ }^{1}$ \\ ${ }^{1}$ University of Darussalam Gontor, Ponorogo, Indonesia \\ *Corresponding author. Email: mohammadghozali@unida.gontor.ac.id
}

\begin{abstract}
Indonesian Freelancers make an extraordinary contribution to the Indonesian economy. This is the impact of successful freelance workers in Indonesia. This freelancing profession raises several cases, one of which is the zakat that must be issued in this profession, with its development in the Industrial Age 4.0. This study aims to review zakat on profession, especially freelancing. This study is based on a literature review using descriptive qualitative methods. The results of this study showed that there are many ikhtilaf about zakat on profession but there is nothing in the Quran and Sunnah that specifically opposes zakat on profession. There are some ulama who oblige and some who do not. Thus, the researcher analyzes that zakat on profession is needed so that the muzakki can carry out their obligations as a Muslim who is faithful and devoted to increasing the economic welfare of the mustahiq with the increasing volume of zakat.
\end{abstract}

Keywords: freelancer, Industry 4.0, zakat on profession

\section{INTRODUCTION}

The industrial world has developed rapidly. From the initial revolution work began to be replaced by steam engines and mechanization until the current revolution, Industry 4.0. Various developments on the steam engine and mechanization then led to electric-powered machines, after which the computer emerged, continuing to facilitate work. In this revolution, various technologies also developed rapidly involving sensors, interconnections and even data analysis. This triggered the idea of integrating the technology into the industrial world, namely Industry 4.0.

The development of interconnection is not only a part of facilitating the work of the previous industrial revolution but also changing the way humans work. This development is able to overcome the problems of space and time, from the process of recruiting employees to the process of completing work. Work processes that are no longer dependent on space and time are starting to become popular in Indonesia. This work process which is commonly called freelance is dominated by the millennial generation. These freelance workers make an extraordinary contribution to the Indonesian macro economy.

The emergence of this type of freelance work raises several cases, one of which is in the field of religion. One of which, in the pillars of Islam, is zakat. Zakat is an obligation for Muslims to give a portion of their wealth to a predetermined group. The development of the times led to many types of new jobs appearing, giving rise to a dilemma of necessity for a wage worker, one of whom is a freelancer who sets aside part of his income as a zakat on profession.

Zakat on Profession is one of the cases in the chapter of Islamic law. Al-Quran and As-Sunnah do not discuss it explicitly. The mujtahid ulama also did not discuss the zakat of this profession due to the lack of types of businesses and occupations at that time. Various developments at this time, especially in the industrial world, led to the emergence of many types of jobs and businesses that did not exist in the early Islamic period. One such job is freelancing. The previous absence of this type of modern work has led to differences of opinion among ulama regarding zakat on profession. Some say it is obliged and some do not. So, it is necessary to analyze zakat on profession of freelancing so that there is clarity of the law [1].

\subsection{Industry 4.0}

The definition of Industry 4.0 varies because it is still in the research and development phase. German Chancellor Angela Merkel believes that Industry 4.0 is a comprehensive transformation of all aspects of production in the industry through the merging of digital and internet technology with conventional industries [2]. Schlechtendahl et al emphasized the definition of the speed element of information availability, which is an industrial environment in which all entities are always connected and able to share information with each other [3].

A more technical understanding was conveyed by Kagermann et al that Industry 4.0 is the integration of the Cyber Physical System (CPS) and the Internet of Things and Services (IoT and IoS into industrial processes including manufacturing, logistics and other processes [4]. CPS is a technology used to combine the real world with the virtual world. This integration can be realized through the integration between physical and computational processes (embedded computers and network technology) in a closed loop [5]. Hermann et al added that Industry 4.0 is a term to refer to a set of technology and value chain organizations in the form of smart factories, CPS, IoT and IoS. Smart factory is a modular factory with CPS technology that monitors the physical processes of production and then displays it virtually and decentralizes decision making. Through IoT, CPS is able to communicate with each other and work together in real time, including with humans. IoS are all service applications that can be utilized by each stakeholder both internally and between organizations. There are six Industry 4.0 design principles namely interoperability, 
virtualization, decentralization, real time capabilities, service orientation and being modular in nature [6].

Based on the above explanations, Industry 4.0 can be interpreted as an industrial era in which all entities in it can communicate with each other in real time at any time based on the use of internet and CPS technology. This is in order to reach the goal of new value creation or optimization of existing values from every process in the industry.

\subsection{Freelancing}

"Life as a freelancer can be described as drifting a bottle containing a message from a desert island, hoping someone will find the bottle and read the message in it, then that person will put something in the bottle to be washed back to you: appreciation, commission, money or love. You must be prepared to accept whatever the contents of the returned bottle are," said the British mystery and fantasy writer, Neil Gaiman, when invited to speak in front of the 2012 class of the University of the Arts in Philadelphia [7].

On this occasion Neil Gaiman also predicted that being a freelancer was one of the career paths that would be increasingly in demand in the future. Neil's prediction, which proved to be true, can be seen from two indicators. First is the rapid development of information and communication technology that makes it easy for humans to move (being borderless) and present various choices in choosing the type of work. Second is the emergence of a variety of new professions in line with the development of information and communication technology, such as freelance writers, journalists, web developers and others [8].

\subsection{Zakat}

In classical fiqh literature the meaning of zakat is the right that is issued from a property or entity. In connection with this, Wahbah al-Zuhayly stated that zakat is a compilation of the rights that are mandatory contained in assets. In the Indonesian language dictionary, a profession is a field of work that is based on a specific education (skills, honesty, etc.) [9]. Zakat on profession is zakat issued from the results of what is obtained from work and profession. For example, work that makes money, whether it's work that is done alone without depending on others, the result of dexterity of the hands, or brain (professional). As well as work done by someone for another party, be it the government, companies, or individuals by obtaining the wages given, by hand, brain or both. Income from such work takes the form of salary, wages or honorarium. That is, if it has reached the Nisab and the haul of the income it generates, it must pay its zakat [10].

Zakat is one of the new cases in figh (Islamic law). AlQuran and al-Sunnah do not contain strict legal rules regarding the zakat on profession. Likewise, mujtahid ulama such as Abu Hanifah, Malik, Shafi'i, and Ahmad ibn Hanbal also did not include in their book's information about the zakat on profession. This is due to the limited types of business or community work during the time of the Prophet and Imam Mujtahid. Islamic law itself is a reflection of the legal events that occurred when the law was established. There is no mention of the emergence of various types of jobs and services or freelancing during the time of the Prophet and the mujtahid ulama, making zakat on profession not so familiar to the modern age in the Sunnah and classical fiqh books. Therefore, it is natural that now there is controversy and differences of opinion among ulama about the zakat on profession. There are ulama who oblige it and there are ulama who do not. However, even though the law regarding the zakat on profession is still controversial and is not well known by the Muslim community in general and Muslim professionals in the country in particular, the awareness and enthusiasm for setting aside part of the income as zakat is believed to be a religious obligation which must be treated with high importance. This discussion forum might be used as an indication of how professionals are very respectful of the zakat on profession [11].

\section{METHOD}

This research is qualitative research and data collection is carried out in library research, data analysis is inductive and the results of qualitative research emphasize the meaning rather than generalization [12]. The analysis that will be used is descriptive analysis that is analyzing data by describing data that has been collected. After data collected the mass of data organized and reduced by selecting, focusing, and transforming data to transcriptions. After the data is reduced the author analyzes the results that have been collected by the zakat profession concept according to Islamic law.

This study discusses the zakat profession of freelancer with the analysis of Islamic Law. The purpose of this study is to describe the definition of Industry 4.0, Freelancer and Zakat Profession in general, the types of professions that have to pay, and how to calculate zakat on profession.

\section{RESULTS AND DISCUSSION}

\subsection{Zakat On Profession: Definition}

Profession according to the Big Indonesian Dictionary (https://kbbi.web.id/) is a field of work which is based on specific skills (academic, vocational, etc.). The term 'profession' in Arabic terminology is not found explicitly because Arabic absorbs only a few foreign languages. In the modern era it is translated into two types of work, work that relies on the brain and work that relies on muscles. Jobs that rely on the brain (teaching, designing, programming etc.) are called Al-mihnah in Arabic. Jobs that rely on muscle (construction, tailoring, blacksmithing etc.) are called Alhirfah [13].

Zakat of income or zakat on profession (al-mal al-mustafad) is zakat that is imposed on any work or on certain professional expertise, whether done alone or together with other people / institutions, which brings halal income (money) that meets the Nisab (minimum limit for 
compulsory zakat). Examples are officials, public or private employees, doctors, consultants, advocates, lecturers, brokers, artists and the like [14].

\subsection{Zakat on Profession: History}

Zakat is one of the pillars of Islam. The change raises several new things related to the zakat case, namely zakat in the professional field. This zakat on profession is qiyas or is equated with zakat of agricultural products. Due to the number of new jobs, the zakat on profession does not appear in the prophetic period. The originator of the zakat on profession is Sheikh Yusuf Qaradhawi in his book Fiqh Az Zakah. Sheikh Abdul Wahhab Khallaf and Sheikh Abu Zahrah were the people who influenced Sheikh Yusuf Qaradhawi in making the book. Zakat on profession itself began to appear in Indonesia in recent years after the book was translated into Indonesian [15].

The imposition of zakat on profession can be seen from two sides.First is the enforcement of economic justice, and secondly it alleviates the burden of zakat payers (muzakki). If it refers to equity and justice in the economy, this can be seen in the Qur'an, so that it will not be a perpetual distribution among the rich from among you (QS. Al-Hasyr: 7). If it serves to alleviate muzakki, then this also has an argument: "O you who have believed, spend your good fortune in the way of Allah (zakat) which is the result of your efforts." (QS. Al-Baqarah: 267)

As for those whose salaries and incomes have not yet reached Nisab, these are then deducted by zakat institutions such as Baznas, with a certain nominal based on regulations issued by the DPRD called regional regulations or issued by local governments in the form of regent regulations. The funds are then included in the infaq category. The regional head has the right to withdraw donations from his people voluntarily or if he sees that in this policy there is a great benefit, both with regards to economic equality among the group of employees who have a steady income to the poor or the seekers of religious knowledge who need help for their survival and education, which is essentially the duty of every Muslim - to help his brother in need.

The opinion that infaq can be strengthened by regulation is also supported by the Prophet's companion, Umar bin AlKhattab who asserted that if given authority as a ruler he would withdraw the wealth of the rich people forcefully or willingly and then distributed to the poor muhajirin [16] Another Prophet's companion, Ali bin Abi Talib, shared this opinion. He said, "Verily, Allah obliges the rich to give their wealth to the poor, just to cover their needs. And if it turns out the poor are abandoned, have no food and clothing and their needs are ignored by the rich, then one day God has the right to judge and punish later." In fact, Abdullah the son of Umar Al-Khattab asserted that in every asset we have, the leaders have rights other than zakat.This last opinion is supported by 300 companions of the Prophet [17].

\subsection{Type of Professions that have to pay Zakat}

A profession is work in the form of services performed either by oneself or in partnership to certain other people or institutions. Earnings from professions are different from those made by farmers, ranchers and merchants. Income is obtained after specialized work is carried out for other people or certain institutions.

Type of profession is divided into two. First is the work done alone without depending on others, the result of dexterity of the hands or the brain. Income obtained in this way is professional income, such as the income of a doctor, engineer, advocate artist, tailor, carpenter etc. Second is the work done by someone for another party, be it the government, companies, or individuals by obtaining wages, which are given, by hand, brain or both. This is done in return for a salary or honorarium such as public or private employment [18].

The growing interconnection technology that is expanding the range of freelancers who generally make direct contracts, is now facilitated by third parties through job opening sites. As a part of Industry 4.0, the development of interconnection has resulted in full time freelance work such as programming, designing, writing, translating and various other types of work which can be carried out without the need for face to face contact.

\subsection{How to Calculate Zakat on Profession}

In the book of zakat fiqh by Dr. Yusuf Qaradlawi, the profession and income chapters explain how to issue income zakat. If we classify this, there are three discourses:

a. Gross expenditure, i.e., zakat gross income. This means that the zakat of income which reaches nisab 85 grams of gold in a year is issued $2.5 \%$ when received before deducting anything. So if you get salary or honorarium and other income in a month that reaches 2 million rupiah $\mathrm{x} 12$ months $=24$ million, it means that you will directly get 2.5 out of 2 million per month $=50$ thousand or get paid at the end of the year $=600$ thousand. This is also based on the opinion of Az-Zuhri and 'Auza'i, as he explained: "If a person earns income and wants to spend it before the obligatory month of zakat comes, then he should immediately issue the zakat first from spending it." (Ibn Abi Syaibah, Al- mushannif, 4/30). Moreover qiyas are equated with some of the zakat property which is immediately issued without deducting anything, such as cattle zakat, gold silver, ma'dzan and rikaz [19].

b. Work operations are deducted, i.e. after receiving salary or honorarium income which reaches nisab, then it is deducted first with work operational costs. For example, a person who gets a salary of 2 million rupiahs a month, minus transportation costs and daily consumption at work as much as 500 thousand, the remaining ends up $1,500,000$ rupiahs. The zakat is then issued 2.5 out of $1,500,000=37,500$. This is analogous to the zakat of 
[4] H. Kagermann, dkk. "Industry 4.0: Mit Dem

crops and dates and the like. The cost is issued first and then the zakat is removed from the rest. It is the opinion of Imam Atho and others, that with regards to zakat of agricultural products there is a difference in the percentage of zakat between those that are irrigated with rain, which is $10 \%$, and through irrigation, $5 \%$ [20].

c. Net expenditure or net zakat, is removing zakat from assets that still reach nisab after being deducted for daily basic needs, both food, shelter, debt and other basic needs for the needs of himself, his family and his dependents. If the income after deducting the basic needs still reaches Nisab, then zakat is obligatory, but if it does not reach the Nisab, then it is not obligatory, because it is not a muzakki (a person who is obliged to pay zakat) and even becomes mustahiq (people who are entitled to receive zakat) because they have become poor with insufficient income for daily basic needs. This is based on the hadith history of Imam Al-Bukhari from Hakim bin Hizam that Rasulullah SAW said: "... and at best the zakat is removed from excess needs..." [21].

\section{CONCLUSION}

The change from Industry 1.0 to 4.0 is very much a drastic change. In principle, Industry 4.0 collaborates between machine, device and human capabilities, thus creating breadth of development in several aspects, including in relation to the profession. This includes the freelance profession. This profession is not bound by time and has no commitment to the company or the people who employ it. Professional zakat is zakat that is issued from the results of work / profession, provided that the nisab and haul have been reached. Freelancing is one of the professions that must be tackled if it is reviewed from several opinions of scholars who require professional zakat. Professional Zakat Freelancers and professional zakat can generally be issued in 2 ways, namely with gross expenditure and net expenditure or net zakat. Freelancer workers in Indonesia are expected to be able to issue zakat as their obligation to become Muslims who are obedient to their Lord and to prosper the lives of mustahiq so that the economy in Indonesia becomes stable.

\section{REFERENCES}

[1] O. Syahroni, dkk, Fikih Zakat Kontemporer, Jakarta: Rajagrafindo Persada, 2018.

[2] M. Angela, "Speech by Federal Chancellor Angela Merkel to The Oecd Conference", https://www.bundesregierung.de/content/en/reden/2014/2014-02-19-oecd-merkelparis_en.html, accessed at 20th of July 2019.

[3] Schlechtendahl, dkk, Making Existing Production Systems Industry 4.0-Ready, Production Engineering, Vol. 9, Issue 1.
Internet Der Dinge Auf Dem Weg Zur 4. Industriellen Revolution", http://www.vdi-nachrichten.com/technikgesellschat/industrie-40-mit-internet-dinge-weg-4industriellen-revolution, accessed at 20th of July 2019. [5] E.A. Lee, Cyber Physical Systems: Design Challenges. In Object Oriented Real-Time Distributed Computing (Isorc), 11th Ieee International Symposium, 2008.

[6] M. Hermann, Dkk, Design Principles for Industrie 4.0 Scenarios. System Sciences (Hicss), 49th Hawaii International Conference, 2016.

[7] Mustofa, "Pekerja Lepas Freelancer Dalam Dunia Bisnis”, Jurnal Mozaik, Vol. 10, Nomor (1), 2018.

[8] Ibid

[9] Muhammad, Zakat Profesi: Wacana Pemikiran Dalam Fiqih Kontemporer, Jakarta: Salemba Diniyah, 2002.

[10] Y. Qardawi, Hukum Zakat, Bogor: Litera Antar Nusa, 2007.

[11] Marimin, T. Nur Fitria, "Zakat Profesi (Zakat Penghasilan) Menurut Hukum Islam”, Jurnal Ilmiah Ekonomi Islam, Vol. 1, Nomor (1), 2015.

[12] Sugiyono, Memahami Penelitian Kualitatif, Bandung: ALFABETA, 2014.

[13] Purwitasari, "Pengertian Islam Profesi dan Profesi Yang Islami”, http://ranumidea.-

blogspot.com/2016/06/makalah-islam-profesi-danprofesi-yang.html, accessed at 20th of July 2019. [14] Navis, "Cara Menghitung Zakat Profesi”, https://islam.nu.or.id/post/-read/9814/cara-menghitungzakat-profesi, accessed at 20th of July 2019.

[15] M. Arifin Badri, "Zakat Profesi Dalam Islam", https://konsultasisyariah.com/320- zakat-profesi-dalamislam.html, accessed at 20th of July 2019.

[16] N. Chamid, Jejak Langkah Sejarah Pemikiran Ekonomi Islam, Yogyakarta: Pustaka Belajar, 2010.

[17] Euis, Sejarah Pemikiran Ekonomi Islam Dari Masa Klasik Hingga Kontemporer, Depok: Gramata Publishing, 2010.

[18] A.Hasan, Tuntunan Puasa dan Zakat, Jakarta: PT. Raja Grafindo Persada, 2001.

[19] Marimin, T. Nur Fitria, "Zakat Profesi (Zakat Penghasilan) Menurut Hukum Islam”...

[20] Y. Qardawi, Hukum Zakat, ...

[21] Ibid 